\title{
Fungal Biosorption for Cadmium and Mercury Heavy Metal Ions Isolated from Some Polluted Localities in KSA
}

\author{
A. Bahobil ${ }^{1}$, R.A. Bayoumi ${ }^{*}$, H.M. Atta ${ }^{2}$ and M.M. El-Sehrawey ${ }^{1,2}$ \\ ${ }^{1}$ Botany and Microbiology Department, Faculty of Science (Bays), Al-Azhar University, \\ Cairo-11884, Egypt \\ ${ }^{2}$ Biology Department, Faculty of Science and Education, Taif University, \\ Al-Khurmah Branch-KSA, Egypt \\ *Corresponding author
}

\section{A B S T R A C T}

Persistent heavy metal pollution poses a major threat to all life forms in the environment due to its toxic effects. These metals are very reactive at low concentrations and can accumulate in the food web, causing severe public health concerns. The use of microbial biosorbents is eco-friendly and cost effective; hence, it is an efficient alternative for the remediation of heavy metal contaminated environments. Microbes have various mechanisms of metal sequestration that hold greater metal biosorption capacities. The goal of microbial biosorption is to remove and/or recover metals and metalloids from solutions,

\section{Keywords}

Biosorption; Cadmium, Mercury, Fungi, Wastewater.

Article Info

Accepted: 26 May 2017 Available Online: 10 June 2017 using living or dead biomass and their components. This paper aims to biosorption of cadmium and mercury heavy metal ions by using some heavy metal ions resistance local fungal isolates with some agricultural wastes for removing it from industrial and municipal wastewater collected from some KSA localities using enrichment culture technique. Eighteen fungal isolates were identified according to key for fungal identification as the following: Acremonium sp., Alternaria alternata, Alternaria chlamydosporum, Aspergillus fumigatus, Aspergillus ochraceus, Aspergillus wentii, Cladosporium cladosporioides, Cunninghamella elegans, Curvularia lunata, Fusarium chlamydosporum, Mucor racemosus, Penicillium aurantiogriseum, Penicillium chrysogenum, Penicillium expansum, Penicillium oxalicum, Rhizopus stolonifer and Trichoderma viride. Two most potent fungal strains viz. Alternaria alternata and Penicillium aurantiogriseum were selected as the most potent fungal strains with tolerant up to $1000 \mathrm{ppm}$ concentration for both $\mathrm{HgCl}_{2}$ and $\mathrm{CdCl}_{2}$ heavy metals. Optimum contact time for Alternaria alternata and Penicillium aurantiogriseum with both heavy metals under investigation (Cadmium and mercury) is five days. The optimum $\mathrm{pH}$ in both cases was 6 . The optimum temperature was $30^{\circ} \mathrm{C}$. The growth of both fungi Alternaria alternata and Penicillium aurantiogriseum on cadmium and mercury ions decreased with increasing of ions concentrations. This indicated the potential of these identified fungi as biosorbent for removal of high concentration metals from wastewater and industrial effluents.

\section{Introduction}

It is well recognized that the presence of heavy metals in the environment can be detrimental to a variety of living species, including man. Industrial wastewaters are considered the most important sources of heavy metal pollution. Heavy metal pollution 
has become a serious environ- mental issue in the last few decades. There is a need to develop potential technology that can remove toxic heavy metals ions found in polluted environments. One of the most serious environmental problems is heavy metal pollution in water and soil. The presence of heavy metals even in traces is toxic and detrimental to both flora and fauna. Wastes containing metals are directly or indirectly being discharged into the environment, which is a serious threat to human life (Ayangbenro, and Babalola, 2017).

Discharge from industry contains various organic and inorganic pollutants. Among these pollutants are heavy metals which can be toxic and / or carcinogenic and which are harmful to humans and other living species (Renge et al., 2012). The heavy metals of most concern from various industries include lead $(\mathrm{Pb})$, zinc $(\mathrm{Zn})$, copper $(\mathrm{Cu})$, arsenic (As), cadmium $(\mathrm{Cd})$, chromium $(\mathrm{Cr})$, nickel (Ni) and mercury (Hg) (Mehdipour et al., 2015). They originate from sources such as metal complex dyes, pesticides, fertilizers, fixing agents (which are added to dyes to improve dye adsorption onto the fibers), mordents, pigments and bleaching agents (Rao et al., 2010).

In developed countries, legislation is becoming increasingly stringent for heavy metal limits in wastewater. Various treatment techniques employed for the removal of heavy metals include chemical precipitation, ion exchange, chemical oxidation, reduction (Electrochemical treatment), reverse osmosis (Membrane technologies), ultra filtration, electrodialysis and adsorption (FU and Wang, 2011). However, some disadvantages, such as high cost, incomplete removal, high-energy consumption, and / or generation of toxic wastes accompany these technologies. Therefore, a cost-effective treatment that efficiently removes heavy metals from industrial effluents is needed.

Among these methods, adsorption is the most efficient as the other technique. Ion exchange, membrane technologies are extremely expensive. An advanced and cost effective technique for the removal of heavy metals from the waste waters has been directed towards biosorption. Some of the promising natural biosorbents like algae, fungi, bacteria and yeast have proved to be potential due to their metal sequestering properties and the tendency for decreasing the concentration of heavy metal ions in the solution (Volesky, 1986).

Microorganisms including fungi and bacteria have been reported to extract heavy metals from wastewater through bioaccumulation and biosorption. Microorganisms can uptake heavy metal ions either actively (bioaccumulation) and /or passively (biosorption). Biosorption refers to the passive heavy metal ions uptake by different forms of biomass, which may be dead or alive. The advantages of biosorption are low cost, high efficiency of heavy metal ions removal from dilute solutions, regeneration and possible metal ions recovery. An attempt was therefore, made to isolate fungi from sites contaminated with heavy metals for higher tolerance and removal from wastewater.

Using microorganisms (i.e. fungi, bacteria, algae and yeasts) as biosorbents to remove metal ions from wastewater offers a potential alternative to existing methods. The adsorption method is a relatively new process and is emerging as a potentially preferred alternative for the removal of heavy metals because it provides flexibility in design, highquality treated effluent and is reversible and the adsorbent can be regenerated (FU and Wang, 2011). 
The major sources of cadmium include metal refineries, smelting, mining and the photographic industry and it is listed as a Category-I carcinogen by the International Agency for Research on Cancer (IARC) and a group B-1 carcinogen by the USEPA (Friberg et al., 1992).

The toxicity of cadmium to microorganisms damage nucleic acid, denature protein, inhibit cell division and transcription, inhibits carbon and nitrogen mineralization (Ayangbenro, and Babalola, 2017), while the toxicity of mercury decrease population size, denature protein, disrupt cell membrane, inhibits enzyme function.

Mercury is also harmful and it is a neurotoxin that can affect the central nervous system. If it is exceeded in concentration, it can cause pulmonary, chest pain and dyspnea (Namasivayam and Kadirvelu, 1999).

In this paper, it has been aimed at portraying the biosorption process, various methods followed for the heavy metal removal from wastewater, and we attempted to optimize the performance of the laboratory scale bioremoval experiments.

The effect of operational conditions (concentrations of cadmium and mercury, contact time, $\mathrm{pH}$, and temperature) were also investigated in this study.

In addition, this paper surveys the various fungal isolates as natural bioadsorpents used as adsorbents and natural biosorbents for the removal of cadmium and mercury from wastewater.

This process obtained from biological material and is comparatively cheap. However, cost analysis is an important criterion for selection of an adsorbent for heavy metal removal from wastewater.

\section{Materials and Methods}

\section{Collection of samples}

Samples of soils, sewage, sludge and industrial effluents were collected in sterilized containers from sewage treatment plants at Taif, KSA. These samples were brought to laboratory and kept in refrigerator at $4{ }^{\circ} \mathrm{C}$ for further processing.

\section{Preparation of heavy metal solutions}

The 1000-ppm stock solutions of $\mathrm{Cd}$ and $\mathrm{Hg}$ ions were made in double distilled water using $\mathrm{CdCl}_{2}$, and $\mathrm{HgCl}_{2}$. The 25, 50, $100,250,500$ and 1000 ppm solutions of these heavy metals were prepared from 1000 ppm stock solution by dilution with double distilled water. The stock solution of heavy metals was sterilized separately through bacteriological filters and added to sterilized potato dextrose and nutrient broth to make its concentration 25, 50,100,250 and $500 \mathrm{ppm}$.

\section{Isolation of heavy metal resistant fungi}

Fungal isolates were isolated from samples of sewage, sludge and industrial effluents by serial dilution method using potato dextrose agar. Heavy metals polluted soil samples were serially diluted up to $10^{9}$ dilutions using sterile saline and the diluted samples are plated on the sterile potato dextrose agar (PDA) plates amended with Mercuric chloride (25, 50, 100, 250, 500 and $1000 \mathrm{ppm})$ and Cadmium chloride $(25,50,100,250,500$ and 1000 ppm) using spread plate method.

The plates incubated at $27^{\circ} \mathrm{C}$ for 4 to 7 days. Plates examined and different isolates further purified by repeated single colony isolation. The fungal isolates identified using cultural morphology, cellular morphology and biochemical tests. Cultural morphology to determine the colony color, shape and texture 
studied on PDA medium. All fungal isolates were maintained on glucose peptone medium containing $20 \mathrm{~g} / \mathrm{l}$ glucose, $20 \mathrm{~g} / \mathrm{l}$ peptone, 5 $\mathrm{g} / \mathrm{l}$ yeast extract, and $15 \mathrm{~g} / \mathrm{l}$ agar, at $\mathrm{pH} 7$ and maintained on GPYA (Glucose Peptone Yeast Extract Agar) medium [composition (g/L): glucose-40; peptone-5; yeast extract-5; agar$30 ; \mathrm{pH}-5.6]$ incubated at room temperature for $48 \mathrm{hrs}$.

\section{Purification}

The purification procedure of the fungal isolates was carried out by the agar streak plate method. All fungal colonies of different forms and colour showing separate growth on both Czapeck-Dox's agar and PDA media were picked up and restreaked following the zig-zag method onto the agar surface of plates containing the same isolation media. At the end of incubation period, only the growth, which appeared as a single separate colony of distinct shape and color, was picked up and restreaked again for several consecutive times onto the surface of agar plate of isolation media to ensure its purity. Purity was checked up microscopically and morphologically. Pure isolates only were subcultured on slants of its specific isolation medium and kept for further investigation. The purified colonies were prepared to be used for a complete identification process and other studies. The pure cultures of were maintained on Potato dextrose agar (PDA) slants at $4^{\circ} \mathrm{C}$.

\section{Identification of heavy metals resistance fungal isolates}

The cultures were identified based on macroscopic (colonial morphology, colour, texture, shape, diameter and appearance of colony) and microscopic characteristics (septation in mycelium, presence of specific reproductive structures, shape and structure of conidia and presence of sterile mycelium). Pure cultures of fungi isolates were identified with the help of literature (Domsch et al., 1980; Barnett and Hunter, 1999).

Parameters controlling the resistance of two most potent fungal strain to cadmium and mercury

To produced mycelium pellets, 6 agar plugs $(5 \mathrm{~mm})$ originating from actively growing seven days old PDA solid cultures (log phase) (Anahid et al.,2011),were collected and inoculated in $250 \mathrm{ml}$ conical flasks containing $(100 \mathrm{ml})$ autoclaved $\left(121^{\circ} \mathrm{C}, 15 \mathrm{~min}\right.$ and 15 psi) potato dextrose broth (PDM) medium. Flasks were incubated in incubator at $28^{\circ} \mathrm{C}$ for 7 days in dark conditions. A 7 days old mycelium was used as the inoculum in the bioaccumulation experiments (Prigione et al., 2009; Kacprzak and Malina, 2005).

Mycelial pellets obtained after incubation periods were harvested through Whatman filter paper No.42 and washed three times with deionized water to remove any residual growth media from biomass. Pellets were heat inactivated by autoclaving and dead biomass was used immediately thereafter (Slaba and Dlugonski, 2011).

An appropriate amount of washed live biomass was dried in oven at $80^{\circ} \mathrm{C}$ overnight. The dried mycelia were grinded using a mortar to obtain powder in the smallest particle size and subsequently used as a biosorbent. The smaller particles resulted in a larger surface area (Zhou, 1999). Biomass has been crushed to prevent particle aggregation for enhancing the biosorption capacity. The dry biomass was stored at room temperature in polyethylene tubes in a vacuum desiccator until use (Ezzouhri et al., 2010).

\section{Effect of contact time}

Time course experiments were conducted in $250 \mathrm{~mL}$ Erlenmeyer flasks with a working 
PDB volume of $100 \mathrm{~mL}$ contaminated with 1000 ppm cadmium and mercury concentrations for two most potent fungal isolates at pH 6 for 1 and 7 days (Kacprzak and Malina, 2005).

\section{Effect of pH}

The bioaccumulation of cadmium and mercury ions by the two most potent fungal isolates was carried out at different $\mathrm{pH}$ ranging from 4-7.5. Fungal inoculated culture medium containing heavy metals was incubated at $\mathrm{pH}$ of $4,4.5,5,5.5,6,6.5,7$ and 7.5.The initial $\mathrm{pH}$ of solutions was adjusted by adding $0.1 \mathrm{M}$ solutions was adjusted by adding $0.1 \mathrm{M} \mathrm{HCL}$ and $0.1 \mathrm{M} \mathrm{NaOH}$. After incubation periods, the culture medium was filtered and the mycelium was weighted.

\section{Effect of temperatures}

Bioaccumulation of cadmium and mercury by the two most potent fungal isolates was carried out at different temperature ranging from 20 to $45^{\circ} \mathrm{C}$. Fungal inoculated culture medium containing cadmium and mercury was at temperature of $20,25,30,35,40$ and $45^{\circ} \mathrm{C}$. After incubation under all optimal conditions, the fungal mycelia were weighted.

The parameters (initial metal concentration, contact time, $\mathrm{pH}$ and temperature), which were considered in a cadmium and mercury biosorption assay by dried mycelia, were the same as those for biosorption by dead mycelia except that $0>2 \mathrm{~g}$ of dried biomass powder was placed in each Erlenmeyer flask.

The effects of initial metal ion, initial $\mathrm{pH}$ and contact time on were examined using one way ANOVA followed by post-Hov multiple comparisons by Duncan's method. The difference was considered significant when $\mathrm{P}<0.05$.

\section{Results and Discussion}

\section{Identification of cadmium and mercury ions resistance fungal isolates}

Eighteen heavy metals fungal isolates were identified of based on macroscopic (colonial morphology, colour, texture, shape, diameter and appearance of colony) and microscopic characteristics (septation in mycelium, presence of specific reproductive structures, shape and structure of conidia and presence of sterile mycelium). Pure cultures of fungi isolates were identified with the help of literature. The heavy metals resistant fungal isolates were identified as Acremonium sp., Alternaria alternata, Alternaria chlamydosporum, Aspergillus fumigatus, Aspergillus ochraceus, Aspergillus wentii, Cladosporium cladosporioides, Cunninghamella elegans, Curvularia lunata, Fusarium chlamydosporum, Mucor racemosus, Penicillium aurantiogriseum, Penicillium chrysogenum, Penicillium expansum, Penicillium oxalicum, Rhizopus stolonifer and Trichoderma viride (Table 1).

\section{Resistance of eighteen heavy metals resistance fungal strains}

Eighteen well identified heavy metals fungal strains were applied against both cadmium and mercuric chloride at different $\mathrm{ppm}$ viz. $25,50,100,250,500$ and $1000 \mathrm{ppm}$ respectively. Three fungal strains Acremonium sp., Fusarium chlamydosporum and Trichoderma viride exhibited high sensitivity to all different cadmium concentrations. Out of eighty fungal strains fifteen, fourteen strains tolerated and resistance to Cadmium at 25 and $50 \mathrm{ppm}$ respectively.

Eleven fungal strains were exhibited resistance to cadmium concentrations at 100 ppm. Six fungal strains were exhibited 
resistance to cadmium concentrations at 250 ppm. Only three fungal strains were exhibited tolerance to cadmium concentrations at $500 \mathrm{ppm}$ viz. Alternaria alternata, Penicillium aurantiogriseum and Penicillium expansum.

Only two fungal strains were exhibited to high resistance to cadmium concentration 1000 ppm viz. Alternaria alternata and Penicillium aurantiogriseum. These two most potent high resistance fungal strains to heavy metals (Cadmium chloride at 1000 ppm) were used to completed study.

These results indicated inhibition of growth of fungal strains at higher concentration of heavy metals. Similar observations about toxic effect of higher concentrations of heavy metals on growth of fungi have been reported by many authors (Table 2 ).

Data recorded in table 3 reveled that only two fungal strains viz. Acremonium $s p$. and Rhizopus stolonifer were sensitive to all mercuric concentration $(25,50,100,250,500$ and $1000 \mathrm{ppm}$ ), while all another tested sixteen strains exhibited resistance to mercuric chloride $25 \mathrm{ppm}$.

Twelve fungal strains were exhibited resistance to mercuric chloride $50 \mathrm{ppm}$ while nine fungal strains exhibited resistance to mercuric chloride 100 ppm. Out of eighty heavy metals, resistance fungal strains only six fungi exhibited resistance to $250 \mathrm{ppm}$ mercuric chloride viz. Alternaria alternata, Aspergillus niger, Aspergillus ochraceus, Penicillium aurantiogriseum, Penicillium expansum and Penicillium oxalicum.

Only three fungal strains exhibited resistance to mercuric chloride (500 ppm) while only two fungal strains exhibited resistance to mercuric chloride (1000 ppm) viz. Alternaria alternata and Penicillium aurantiogriseum.
Parameters affecting the growth of the potent two fungal strains Alternaria alternata and Penicillium aurantiogriseum on cadmium and mercury respectively

\section{Contact time}

An increase in percentage of biosorption for cadmium and mercury by Alternaria alternata and Penicillium aurantiogriseum was observed time increased and later decreased after a longer time as shown in table 4.

\section{pH}

The effect of $\mathrm{pH}$ on percentage biosorption of heavy metals is depicted in table 5 for both cadmium and mercury by using Alternaria alternata and Penicillium aurantiogriseum, the sorption increased at $\mathrm{pH}$ 6. This implies that an optimum percentage of biosorption was achieved at $\mathrm{pH}$ between 5 and 6 .

\section{Temperature}

The sorption percentage increased with temperature for the heavy metals and experienced a significant reduction after the optimum temperature was reached. The maximum biosorption capacity of the biosorbent for cadmium and mercury by Alternaria alternata and Penicillium aurantiogriseum was achieved at temperature of $30^{\circ} \mathrm{C}$. Further increase in temperature gave low effect or no on sorption percentage (Fungal growth). Therefore, the optimum temperature needed for the effective biosorption of the heavy metals in this experiment for the cadmium and mercury metals range from $25^{\circ} \mathrm{C}$ to $35^{\circ} \mathrm{C}$ (Table 6).

\section{Heavy metals concentrations}

The growth of Alternaria alternata and Penicillium aurantiogriseum at different concentrations of two tested heavy metals 
cadmium and mercury were decreased with increasing concentrations from $25-1000$ ppm. If the toxicity of cadmium and mercury increased the growth of two most potent fungi decreased (Table 7).

Once toxic metals are present in the environment, they are cycled between its abiotic and biotic elements, posing toxicity in the latter group. The most dangerous metals the so-called "toxic trio" i.e. cadmium $(\mathrm{Cd})$, lead and mercury for which no biological function has been found (Chojnacka, 2010).

Biosorption, bioaccumulation, biotransformation, and bio mineralization are the techniques employed by microorganisms for their continued existence in metal polluted environment. These strategies have been exploited for remediation procedures (Gadd, 2010; Lin and Lin, 2005). Heavy metal removal can be carried out by living organisms or dead biological materials. Large scale feasibility applications of biosorptive processes have shown that dead biomass is more applicable than the bioaccumulation approach, which involves the use of living organisms and thus requires nutrient supply and a complicated bioreactor system. In addition, the toxicity of pollutants, as well as other unfavorable environmental conditions, can contribute to the inability to maintain a healthy microbial population.

The cellular structure of a microorganism can trap heavy metal ions and subsequently adsorb them onto the binding sites of the cell wall (Malik, 2004).

This process is called biosorption or passive uptake, and is independent of the metabolic cycle. The amount of metal sorbed depends on the kinetic equilibrium and composition of the metal at the cellular surface. The mechanism involves several processes, including electrostatic interaction, ion exchange, precipitation, the redox process, and surface complexation (Yang et al., 2015).

However, many characteristic attributes of living microorganisms have not been exploited in large-scale applications (Park et $a l ., 2010)$. The choice organism must develop resistance towards metal ions as it comes into contact with the heavy metal pollutant to achieve the goal of remediation. The organism of choice may be native to the polluted environment or isolated from another environment and brought to the contaminated site (Sharma et al., 2000).

Biotic methods exploit natural biological processes that allow certain plants and microorganisms to help in the remediation of metals in soil and water (Hashim et al., 2011). Bioremediation is gaining importance in recent times as an alternate technology for the removal of elemental pollutants in soil and water, which require effective methods of decontamination (Srivastava and Majumder, 2008).

Biosorption and bioaccumulation are two processes involved in biotreatment studies. Heavy metal bioaccumulation is as active process including metabolic activity within living organisms (Lesmana et al., 2009). Biosorption is a term that usually describes the removal of heavy metals from an aqueous solution through their passive binding to a biomass (Pacheco et al., 2011). In bioaccumulation, the first stage is biosorption and then, subsequent stages, related to the transport of pollutant (mainly via energyconsuming active transport systems) into the inside of cells occur (Chojnacka, 2010). Apart from using living biomass, dead and dried biomasses have been introduced as anew field of bio treatment technology. Many studies have revealed that inactive/dead microbial biomass can passively bind metal ions via various physicochemical mechanisms (Wang 
and Chen, 2009)). It has been suggested that the pretreatment modifies the surface characteristics/ groups or by exposing more metal- binding sites (Dhankhar and Hooda, 2011).

Eighteen fungal isolates tolerant to heavy metals were isolated from samples of soil, sewage, sludge and industrial effluent contaminated with heavy metals using standard methods (Solarsk et al., 2009). Out of eighteen three fungal strains Acremonium sp., Fusarium chlamydosporum and Trichoderma viride exhibited high sensitivity to all cadmium contraptions. Only three fungal strains were exhibited tolerance to cadmium concentrations at 500 ppm viz. Alternaria alternata, Penicillium aurantiogriseum and Penicillium expansum. Only two fungal strains were exhibited to high resistance to cadmium concentration 1000 ppm viz. Alternaria alternata and Penicillium aurantiogriseum.

Twelve fungal strains were exhibited resistance to mercuric chloride $50 \mathrm{ppm}$ while nine fungal strains exhibited resistance to mercuric chloride 100 ppm. Out of eighty heavy metals, resistance fungal strains only six fungi exhibited resistance to $250 \mathrm{ppm}$ mercuric chloride viz. Alternaria alternata, Aspergillus niger, Aspergillus ochraceus, Penicillium aurantiogriseum, Penicillium expansum and Penicillium oxalicum. Only three fungal strains exhibited resistance to mercuric chloride (500 ppm) while only two fungal strains exhibited resistance to mercuric chloride (1000 ppm) viz. Alternaria alternata and Penicillium aurantiogriseum.

This indicated inhibition of growth of the fungal isolates at higher concentration of two heavy metals. Similar observations about toxic effect of higher concentration of heavy metals on growth of fungi and bacteria have been reported (Malik, 2004; Rama et al., 1997).

The maximum uptake of $1000 \mathrm{ppm}$ of cadmium was observed Alternaria alternata and Penicillium aurantiogriseum. Also maximum uptake of mercury $1000 \mathrm{ppm}$ found in Alternaria alternata and Penicillium aurantiogriseum.

The minimum uptake of 1000ppm of mercury was observed with Alternaria alternata and Penicillium aurantiogriseum. Wherever there was less growth, there was higher uptake of cadmium and vice versa.

Table.1 Identification of eighteen isolates cadmium and mercury ions resistance fungal isolates

\begin{tabular}{|c|l|c|l|}
\hline No. & Heavy metals resistance fungi & No. & Heavy metals resistance fungi \\
\hline 1 & Acremonium sp. & 10 & Curvularia lunata \\
\hline 2 & Alternaria alternata & 11 & Fusarium chlamydosporum \\
\hline 3 & Alternaria chlamydosporum & 12 & Mucor racemosus \\
\hline 4 & Aspergillus fumigatus & 13 & Penicillium aurantiogriseum \\
\hline 5 & Aspergillus niger & 14 & Penicillium chrysogenum \\
\hline 6 & Aspergillus ochraceus & 15 & Penicillium expansum \\
\hline 7 & Aspergillus wentii & 16 & Penicillium oxalicum \\
\hline 8 & Cladosporium cladosporioides & 17 & Rhizopus stolonifer \\
\hline 9 & Cunninghamella elegans & 18 & Trichoderma viride \\
\hline
\end{tabular}


Table.2 Effect of Cadmium ions concentration (ppm) on the growth of Eighteen identified fungal strains

\begin{tabular}{|c|c|c|c|c|c|c|c|c|}
\hline \multirow[t]{2}{*}{ No. } & \multirow{2}{*}{$\mathrm{Z}_{\substack{\text { Organism } \\
\text { Heavy Metal Conc. }}}$} & \multirow{2}{*}{$\begin{array}{l}\text { Control } \\
\text { (Without } \\
\left.\mathrm{CdCl}_{2}\right)\end{array}$} & \multicolumn{6}{|c|}{ Cadmium concentrations (ppm) } \\
\hline & & & 25 & 50 & 100 & 250 & 500 & 1000 \\
\hline 1 & Acremonium sp. & $9.8 \pm 0.6$ & -ve & -ve & -ve & -ve & -ve & -ve \\
\hline 2 & Alternaria alternata & $13.5 \pm 2.4$ & $12.6 \pm 1.8$ & $10.8 \pm 2.1$ & $9.7 \pm 1.1$ & $6.1 \pm 0.7$ & $3.8 \pm 0.9$ & $1.9 \pm 0.4$ \\
\hline 3 & Alternaria chlamydosporum & $15.8 \pm 1.3$ & $10.9 \pm 1.2$ & $7.6 \pm 0.8$ & $3.8 \pm 0.4$ & $1.3 \pm 0.4$ & $-\mathrm{ve}$ & $-v e$ \\
\hline 4 & Aspergillus fumigatus & $13.9 \pm 1.7$ & $10.5 \pm 1.2$ & $8.1 \pm 0.7$ & $1.9 \pm 0.6$ & $-\mathrm{ve}$ & -ve & -ve \\
\hline 5 & Aspergillus niger & $17.9 \pm 3.2$ & $12.3 \pm 1.7$ & $8.8 \pm 0.9$ & $3.6 \pm 0.7$ & $-\mathrm{ve}$ & -ve & -ve \\
\hline 6 & Aspergillus ochraceus & $14.6 \pm 1.8$ & $9.7 \pm 1.1$ & $6.3 \pm 0.5$ & $2.4 \pm 0.6$ & $-\mathrm{ve}$ & $-\mathrm{ve}$ & $-\mathrm{ve}$ \\
\hline 7 & Aspergillus wentii & $12.3 \pm 0.5$ & $8.6 \pm 0.4$ & $5.9 \pm 0.5$ & $1.4 \pm 0.3$ & $-\mathrm{ve}$ & $-\mathrm{ve}$ & $-\mathrm{ve}$ \\
\hline 8 & Cladosporium cladosporioides & $13.5 \pm 0.7$ & $8.7 \pm 0.9$ & $4.8 \pm 0.6$ & $1.7 \pm 0.4$ & -ve & -ve & -ve \\
\hline 9 & Cunninghamella elegans & $11.3 \pm 0.9$ & $6.1 \pm 0.3$ & $3.9 \pm 0.5$ & -ve & -ve & -ve & -ve \\
\hline 10 & Curvularia lunata & $12.4 \pm 0.9$ & $6.5 \pm 1.7$ & $2.6 \pm 0.5$ & $-\mathrm{ve}$ & $-\mathrm{ve}$ & $-\mathrm{ve}$ & $-\mathrm{ve}$ \\
\hline 11 & Fusarium chlamydosporum & $10.2 \pm 0.6$ & $-\mathrm{ve}$ & $-\mathrm{ve}$ & $-\mathrm{ve}$ & $-\mathrm{ve}$ & $-\mathrm{ve}$ & $-\mathrm{ve}$ \\
\hline 12 & Mucor racemosus & $9.4 \pm 0.6$ & $5.7 \pm 0.9$ & $4.2 \pm 0.6$ & $-\mathrm{ve}$ & -ve & $-\mathrm{ve}$ & -ve \\
\hline 13 & Penicillium aurantiogriseum & $11.3 \pm 2.1$ & $10.7 \pm 1.8$ & $10.2 \pm 2.1$ & $8.9 \pm 0.8$ & $4.6 \pm 0.6$ & $1.1 \pm 0.3$ & $0.4 \pm 0.1$ \\
\hline 14 & Penicillium chrysogenum & $10.8 \pm 0.6$ & $6.3 \pm 1.2$ & $4.9 \pm 0.7$ & $1.7 \pm 0.9$ & $0.8 \pm 0.3$ & $-\mathrm{ve}$ & $-v e$ \\
\hline 15 & Penicillium expansum & $12.7 \pm 1.2$ & $10.3 \pm 1.4$ & $9.0 \pm 0.8$ & $7.9 \pm 1.2$ & $3.1 \pm 0.5$ & $0.8 \pm 0.3$ & -ve \\
\hline 16 & Penicillium oxalicum & $10.9 \pm 0.8$ & $8.6 \pm 0.4$ & $8.2 \pm 0.9$ & $6.5 \pm 0.9$ & $3.8 \pm 0.6$ & $-\mathrm{ve}$ & -ve \\
\hline 17 & Rhizopus stolonifer & $8.7 \pm 0.9$ & $3.6 \pm 0.8$ & $-\mathrm{ve}$ & $-\mathrm{ve}$ & $-\mathrm{ve}$ & -ve & -ve \\
\hline 18 & Trichoderma viride & $11.2 \pm 1.4$ & -ve & -ve & $-\mathrm{ve}$ & -ve & -ve & $-\mathrm{ve}$ \\
\hline
\end{tabular}

The data are expressed as fresh weight (in grams) \pm standard deviation of three independent experiments.

Table.3 Effect of Mercury (Hg) ions concentration (ppm) on the growth of certain fungal species

\begin{tabular}{|c|c|c|c|c|c|c|c|c|}
\hline \multirow[t]{2}{*}{ No. } & \multirow{2}{*}{ Heavy Metal Conc. } & \multirow{2}{*}{$\begin{array}{l}\text { Control } \\
\text { (Without } \\
\mathrm{HgCl}_{2} \text { ) }\end{array}$} & \multicolumn{6}{|c|}{ Mercuric Concentrations (ppm) } \\
\hline & & & 25 & 50 & 100 & 250 & 500 & 1000 \\
\hline 1 & Acremonium sp. & $9.8 \pm 0.6$ & $-\mathrm{ve}$ & $-\mathrm{ve}$ & -ve & -ve & $-\mathrm{ve}$ & -ve \\
\hline 2 & Alternaria alternata & $12.6 \pm 1.7$ & $9.7 \pm 1.9$ & $9.2 \pm 2.3$ & $7.3 \pm 1.2$ & $5.2 \pm 0.9$ & $2.3 \pm 0.6$ & $1.1 \pm 0.3$ \\
\hline 3 & Alternaria chlamydosporum & $15.8 \pm 1.3$ & $8.3 \pm 0.7$ & $1.4 \pm 0.5$ & $-\mathrm{ve}$ & -ve & -ve & -ve \\
\hline 4 & Aspergillus fumigatus & $13.9 \pm 1.7$ & $8.9 \pm 0.8$ & $5.2 \pm 0.6$ & $2.1 \pm 0.3$ & -ve & -ve & $-\mathrm{ve}$ \\
\hline 5 & Aspergillus niger & $18.7 \pm 2.4$ & $17.4 \pm 1.6$ & $15.6 \pm 2.3$ & $14.2 \pm 0.9$ & $8.6 \pm 0.4$ & $0.8 \pm 0.1$ & $-\mathrm{ve}$ \\
\hline 6 & Aspergillus ochraceus & $14.6 \pm 1.8$ & $10.6 \pm 0.8$ & $7.9 \pm 0.8$ & $3.5 \pm 1.3$ & $1.1 \pm 0.4$ & $-\mathrm{ve}$ & $-\mathrm{ve}$ \\
\hline 7 & Aspergillus wentii & $12.3 \pm 0.5$ & $4.3 \pm 0.8$ & $-\mathrm{ve}$ & $-\mathrm{ve}$ & $-\mathrm{ve}$ & $-\mathrm{ve}$ & $-\mathrm{ve}$ \\
\hline 8 & Cladosporium cladosporioides & $13.5 \pm 0.7$ & $6.3 \pm 0.8$ & $3.7 \pm 0.5$ & -ve & $-\mathrm{ve}$ & $-\mathrm{ve}$ & $-\mathrm{ve}$ \\
\hline 9 & Cunninghamella elegans & $11.3 \pm 0.9$ & $5.8 \pm 0.4$ & $1.9 \pm 0.7$ & $-\mathrm{ve}$ & $-\mathrm{ve}$ & $-\mathrm{ve}$ & $-\mathrm{ve}$ \\
\hline 10 & Curvularia lunata & $12.4 \pm 0.9$ & $4.9 \pm 0.8$ & $-\mathrm{ve}$ & -ve & $-\mathrm{ve}$ & $-\mathrm{ve}$ & $-\mathrm{ve}$ \\
\hline 11 & Fusarium chlamydosporum & $10.2 \pm 0.6$ & $7.4 \pm 0.7$ & $3.8 \pm 0.6$ & $1.2 \pm 0.4$ & $-\mathrm{ve}$ & $-\mathrm{ve}$ & $-\mathrm{ve}$ \\
\hline 12 & Mucor racemosus & $9.4 \pm 0.6$ & $2.4 \pm 0.7$ & $-\mathrm{ve}$ & $-\mathrm{ve}$ & $-\mathrm{ve}$ & $-\mathrm{ve}$ & -ve \\
\hline 13 & Penicillium aurantiogriseum & $10.8 \pm 1.5$ & $9.1 \pm 0.8$ & $8.5 \pm 1.7$ & $7.9 \pm 0.6$ & $4.8 \pm 0.7$ & $1.6 \pm 0.3$ & $0.7 \pm 0.1$ \\
\hline 14 & Penicillium chrysogenum & $10.8 \pm 0.6$ & $8.1 \pm 0.7$ & $5.7 \pm 0.8$ & $2.9 \pm 0.4$ & $-\mathrm{ve}$ & $-\mathrm{ve}$ & -ve \\
\hline 15 & Penicillium expansum & $12.7 \pm 1.2$ & $9.6 \pm 0.3$ & $6.8 \pm 0.6$ & $3.8 \pm 0.4$ & $1.5 \pm 0.6$ & $-\mathrm{ve}$ & $-\mathrm{ve}$ \\
\hline 16 & Penicillium oxalicum & $10.9 \pm 0.8$ & $8.9 \pm 0.8$ & $7.4 \pm 0.6$ & $5.3 \pm 0.5$ & $1.9 \pm 0.5$ & -ve & $-\mathrm{ve}$ \\
\hline 17 & Rhizopus stolonifer & $8.7 \pm 0.9$ & $-\mathrm{ve}$ & $-\mathrm{ve}$ & $-\mathrm{ve}$ & $-\mathrm{ve}$ & -ve & $-\mathrm{ve}$ \\
\hline 18 & Trichoderma viride & $11.2 \pm 1.4$ & $4.1 \pm 0.6$ & $-\mathrm{ve}$ & $-\mathrm{ve}$ & $-\mathrm{ve}$ & -ve & -ve \\
\hline
\end{tabular}

The data expressed as fresh weight in grams \pm standard deviation of three independent experiments. 
Table.4 Effect of contact time into growth of two most potent fungal strains that incubated for 48, 72, 96, 120,144,168 and 192 hours with cadmium chloride and mercuric chloride (1000ppm)

\begin{tabular}{|c|c|c|c|c|c|}
\hline \multicolumn{3}{|c|}{ Cadmium chloride uptake } & \multicolumn{3}{c|}{ Mercuric chloride uptake } \\
\hline $\begin{array}{c}\text { Contact } \\
\text { time } \\
(\mathrm{h})\end{array}$ & $\begin{array}{c}\text { Alternaria } \\
\text { alternata } \text { dry } \\
\text { weight }(\mathrm{g} / 100 \mathrm{ml})\end{array}$ & $\begin{array}{c}\text { Penicillium } \\
\text { aurantiogriseum } \\
\text { dry weight } \\
(\mathrm{g} / 100 \mathrm{ml}\end{array}$ & $\begin{array}{c}\text { Contact } \\
\text { time } \\
(\mathrm{h})\end{array}$ & $\begin{array}{c}\text { Alternaria } \\
\text { alternata } \\
\text { dry } \\
\text { weight } \\
(\mathrm{g} / 100 \mathrm{ml})\end{array}$ & $\begin{array}{c}\text { Penicillium } \\
\text { aurantiogriseum } \\
\text { dry weight } \\
(\mathrm{g} / 100 \mathrm{ml}\end{array}$ \\
\hline 48 & $1.99 \pm 0.5$ & $0.41 \pm 1.3$ & 48 & $1.12 \pm 0.8$ & $0.71 \pm 0.4$ \\
\hline 72 & $2.21 \pm 0.3$ & $0.52 \pm 0.9$ & 72 & $1.32 \pm 1.2$ & $0.82 \pm 0.6$ \\
\hline 96 & $2.42 \pm 0.4$ & $0.67 \pm 0.4$ & 96 & $1.45 \pm 0.7$ & $0.91 \pm 0.1$ \\
\hline 144 & $2.45 \pm 0.3$ & $0.82 \pm 0.6$ & 144 & $1.50 \pm 0.3$ & $0.99 \pm 0.5$ \\
\hline 168 & $2.23 \pm 0.3$ & $0.81 \pm 0.1$ & 168 & $1.44 \pm 1.7$ & $0.90 \pm 1.7$ \\
\hline 192 & $2.22 \pm 0.1$ & $0.81 \pm 1.4$ & 192 & $1.43 \pm 0.2$ & $0.90 \pm 1.6$ \\
\hline
\end{tabular}

Table.5 Effect of different $\mathrm{pH}$ values on the growth of two fungal strains Alternaria alternata and Penicillium aurantiogriseum on cadmium and mercury

\begin{tabular}{|c|c|c|c|c|c|}
\hline \multicolumn{3}{|c|}{ Cadmium chloride uptake } & \multicolumn{3}{c|}{ Mercuric chloride uptake } \\
\hline $\mathrm{pH}$ & $\begin{array}{c}\text { Alternaria } \\
\text { alternata } \text { dry } \\
\text { weight } \\
(\mathrm{g} / 100 \mathrm{ml})\end{array}$ & $\begin{array}{c}\text { Penicillium } \\
\text { aurantiogriseum } \\
\text { dry weight } \\
(\mathrm{g} / 100 \mathrm{ml})\end{array}$ & $\mathrm{pH}$ & $\begin{array}{c}\text { Alternaria } \\
\text { alternata } \text { dry } \\
\text { weight } \\
(\mathrm{g} / 100 \mathrm{ml})\end{array}$ & $\begin{array}{c}\text { Penicillium } \\
\text { aurantiogriseum } \\
\text { dry weight } \\
(\mathrm{g} / 100 \mathrm{ml})\end{array}$ \\
\hline 4 & $2.12 \pm 0.1$ & $1.60 \pm 0.2$ & 4 & $1.30 \pm 0.2$ & $0.90 \pm 0.1$ \\
\hline 4.5 & $2.23 \pm 0.2$ & $1.62 \pm 0.3$ & 4.5 & $1.33 \pm 0.1$ & $0.95 \pm 0.2$ \\
\hline 5 & $2.34 \pm 0.1$ & $1.70 \pm 0.2$ & 5 & $1.49 \pm 0.4$ & $0.96 \pm 0.1$ \\
\hline 5.5 & $2.41 \pm 0.1$ & $1.81 \pm 0.1$ & 5.5 & $1.51 \pm 0.5$ & $0.98 \pm 0.1$ \\
\hline 6 & $2.48 \pm 0.2$ & $1.82 \pm 0.1$ & 6 & $1.50 \pm 0.1$ & $0.99 \pm 0.2$ \\
\hline 6.5 & $2.45 \pm 0.4$ & $1.81 \pm 0.4$ & 6.5 & $1.49 \pm 0.1$ & $0.97 \pm 0.1$ \\
\hline 7 & $2.44 \pm 0.1$ & $1.80 \pm 0.1$ & 7 & $1.44 \pm 0.3$ & $0.96 \pm 0.1$ \\
\hline 7.5 & $2.10 \pm 0.3$ & $1.70 \pm 0.1$ & 7.5 & $1.22 \pm 0.3$ & $0.96 \pm 0.2$ \\
\hline
\end{tabular}

Table.6 Effect of temperature on the growth of two fungal strains Alternaria alternata and Penicillium aurantiogriseum on cadmium and mercury

\begin{tabular}{|c|c|c|c|c|c|}
\hline \multicolumn{3}{|c|}{ Cadmium chloride uptake } & \multicolumn{3}{c|}{ Mercuric chloride uptake } \\
\hline $\begin{array}{c}\text { Temperature } \\
\left({ }^{\circ} \mathrm{C}\right)\end{array}$ & $\begin{array}{c}\text { Alternaria } \\
\text { alternata } \\
\text { dry weight } \\
(\mathrm{g} / 100 \mathrm{ml})\end{array}$ & $\begin{array}{c}\text { Penicillium } \\
\text { aurantiogriseum } \\
\text { dry weight } \\
(\mathrm{g} / 100 \mathrm{ml})\end{array}$ & $\begin{array}{c}\text { Temperature } \\
\left({ }^{\circ} \mathrm{C}\right)\end{array}$ & $\begin{array}{c}\text { Alternaria } \\
\text { alternata } \\
\text { dry weight } \\
(\mathrm{g} / 100 \mathrm{ml})\end{array}$ & $\begin{array}{c}\text { Penicillium } \\
\text { aurantiogriseum } \\
\text { dry weight } \\
(\mathrm{g} / 100 \mathrm{ml})\end{array}$ \\
\hline 20 & $2.39 \pm 0.5$ & $1.50 \pm 0.2$ & 20 & $1.75 \pm 0.1$ & $0.85 \pm 0.1$ \\
\hline 25 & $2.48 \pm 0.12$ & $1.51 \pm 0.1$ & 25 & $1.81 \pm 0.4$ & $0.99 \pm 0.1$ \\
\hline 30 & $2.54 \pm 0.1$ & $1.50 \pm 0.1$ & 30 & $1.82 \pm 0.1$ & $0.99 \pm 0.0$ \\
\hline 35 & $2.11 \pm 0.1$ & $1.44 \pm 0.2$ & 35 & $1.80 \pm 0.2$ & $0.85 \pm 0.0$ \\
\hline 40 & $1.51 \pm 0.2$ & $1.43 \pm 0.2$ & 40 & $1.80 \pm 0.1$ & $0.80 \pm 0.1$ \\
\hline 45 & $1.22 \pm 0.5$ & $1.42 \pm 0.4$ & 45 & $1.71 \pm 0.2$ & $0.77 \pm 0.0$ \\
\hline
\end{tabular}


Table.7 Effect of different contraptions (ppm) of cadmium and mercury on the growth of two fungal strains Alternaria alternata and Penicillium aurantiogriseum on cadmium and mercury

\begin{tabular}{|c|c|c|c|c|c|}
\hline \multicolumn{3}{|c|}{ Cadmium chloride uptake } & \multicolumn{3}{c|}{ Mercuric chloride uptake } \\
\hline $\begin{array}{c}\text { Concent- } \\
\text { rations } \\
(\mathrm{ppm})\end{array}$ & $\begin{array}{c}\text { Alternaria } \\
\text { alternata } \text { dry } \\
\text { weight } \\
(\mathrm{g} / 100 \mathrm{ml})\end{array}$ & $\begin{array}{c}\text { Penicillium } \\
\text { aurantiogriseum } \\
\text { dry weight } \\
(\mathrm{g} / 100 \mathrm{ml})\end{array}$ & $\begin{array}{c}\text { Concent } \\
\text {-rations } \\
(\mathrm{ppm})\end{array}$ & $\begin{array}{c}\text { Alternaria } \\
\text { alternata } \\
\text { dry weight } \\
(\mathrm{g} / 100 \mathrm{ml})\end{array}$ & $\begin{array}{c}\text { Penicillium } \\
\text { aurantiogriseum } \\
\text { dry weight } \\
(\mathrm{g} / 100 \mathrm{ml})\end{array}$ \\
\hline 25 & $13.4 \pm 0.1$ & $11.2 \pm 0.3$ & 25 & $10.7 \pm 0.2$ & $10.3 \pm 0.2$ \\
\hline 50 & $12.5 \pm 0.5$ & $10.5 \pm 0.1$ & 50 & $9.5 \pm 0.1$ & $9.1 \pm 0.1$ \\
\hline 100 & $10.2 \pm 0.2$ & $9.2 \pm 0.2$ & 100 & $8.2 \pm 0.2$ & $8.5 \pm 0.1$ \\
\hline 250 & $7.5 \pm 0.1$ & $5.1 \pm 0.4$ & 250 & $5.9 \pm 0.1$ & $5.6 \pm 0.2$ \\
\hline 500 & $4.3 \pm 0.1$ & $2.4 \pm 0.1$ & 500 & $2.9 \pm 0.5$ & $2.1 \pm 0.1$ \\
\hline 1000 & $2.5 \pm 0.2$ & $0.8 \pm 0.1$ & 1000 & $2.5 \pm 0.2$ & $1.8 \pm 0.1$ \\
\hline
\end{tabular}

The highest uptake of cadmium and mercury by Alternaria alternata and Penicillium aurantiogriseum isolates indicated more binding sites on cell wall of these fungal strains and their potential as biosorbent to remove cadmium and mercury from soil, sewage, wastewater and industrial wastewater containing higher concentration of cadmium and mercury.

These results showed that both Alternaria alternata and Penicillium aurantiogriseum are suitable for using as cadmium and mercury accumulators in wastewater. Similar results with respect to biosorption of cadmium and other heavy metals by fungi and bacteria have been reported earlier (Chang et al., 1997; Puranik and Paknikar, 1999; Costa et al., 2001; Pardo et al., 2003; Kefala et al., 1999; Ghoslan et al., 1999; Say et al., 2001; Watanabe et al., 2003; Ozdemir et al., 2004; Ayangbenro, and Babalola, 2017).

Kumar et al., (2014) isolated five fungi that tolerate $\mathrm{Pb}, \mathrm{Cd}$ and $\mathrm{Cr}$. Penicillium chrysogenum, Aspergillus nidulans, Aspergillus flavus, Rhizopus arrhizus, Trichoderma viride. Fungi Aspergillus nidulans, Rhizopus arrhizus and Trichoderma viride showed maximum uptake capacity of $25.67 \mathrm{mg} / \mathrm{g}$ for $\mathrm{Pb}, 13.15 \mathrm{mg} / \mathrm{g}$ for $\mathrm{Cd}$ and
$2.55 \mathrm{mg} / \mathrm{g}$ of Cr respectively. Fungal biomass has been explored by several researchers for its potential to remove copper from wastewater. The use of fungal biomass for such purposes has been hindered due to problems such as small particle size, poor mechanical strength, low density and rigidity (Ayangbenro and Babalola, 2017).

However, the use of a suitable matrix can potentially overcome these problems. Thus, Iqbal and Edyvean (2004) used a low cost, physically strong and highly porous matrix, namely" Loofah sponge" for the immobilized biomass of Phanerochaete chrysosporium, and a maximum adsorption capacity of 50.9 $\mathrm{mg} / \mathrm{g}$ at $\mathrm{pH} 6$ with $98 \%$ removal reported.

The fungi has highly porous, their mesh structure provides ready access and a large surface area for the biosorption.

Numerous studies have demonstrated that microorganisms have ability to remove heavy metals from wastewater with better performance and lower cost compared with conventional technologies (Congeevaram et al., 2007).

Various researchers have shown that Aspergillus niger can effectively remove 
uranium, lead, cadmium and copper ions (Kapoor et al., 1999). Huang and Huang (1996) and Huang et al., (1988) investigated the use of Aspergillus oryzae to remove cadmium and copper ions from aqueous solution.

Small particle size with low density, poor mechanical strength and rigidity are some of the physical problems encountered when applying biomass as a biosorbent (Han et al., 2005). Immobilization of the biomass within a suitable matrix can overcome these problems by offering ideal size, mechanical strength, rigidity and porous characteristics to the biological material (Trujillo et al., 1995).

Several immobilized biomass systems have been successfully used as adsorbing agents to remove heavy metals (Pan et al., 2005). Loofa sponge is a natural, environmentally friendly biomaterial. It is abundant, cheap, rigid, nontoxic, chemically inert and highly porous. The use of loofa sponge material for the immobilization of algae, fungal hyphae and yeast cells has been successfully demonstrated (Akhtar et al., 2008). However, the use of loofa sponge- immobilized Aspergillus terreus for metal biosorption has not been investigated. Ho et al., (2006) reported that free Aspergillus terreus has high capacity for adsorbing metal ions from aqueous solutions. Sun et al., (2010) studied that lead, mercury and cadmium biosorption from solutions by loofa sponge immobilized Aspergillus terreus and evaluate the applicability of the immobilized Aspergillus terreus for the removal of lead from industrial wastewaters.

Various factors influence the microbial remediation of metals. They include the bioavailability of the metal to the microbe, concentration of pollutants, electron acceptors, moisture content, nutrients, osmotic pressure, oxygen, $\mathrm{pH}$, redox potential, soil structure, temperature, and water activity. The bioavailability of each metal in soil is influenced by factors such as the buffering capacity, cation exchange capacity, clay minerals content, metal oxide, and organic matter (Tak et al.,2013; Mani and Kumar,2014; Brar et al.,2006).

Although some heavy metals play important roles in the physiological, biochemical, and metabolic processes of living organisms, functioning as co-factors for some enzymes, micronutrients, regulators of osmotic pressure, and stabilization of molecules, the majority of them have no known biological function in living organisms and are toxic when generated in excess (Fachola et al., 2016). The toxicity of metals is the ability of a metal to cause undesirable effects on organisms. This depends on the heavy metal bioavailability and the absorbed dose (Rasmussen et al., 2000). The threat posed by heavy metals to the health of living organisms is worsened by their continuously persistent nature in the environment. Toxicity increases when the medium becomes acidic and nutrient-deficient, and when the soil structure is poor, especially in mining environments (Mukhopadhyay and Maiti, 2010).

At acidic $\mathrm{pH}$ levels, heavy metals tend to form free ionic species, with more protons available to saturate metal binding sites. This means that at higher hydrogen ion concentrations, the adsorbent surface is further positively charged, thus reducing the attraction between adsorbent and metal cations.

Therefore, heavy metal becomes more bioavailable, thereby increasing its toxicity to microorganisms and plants. At basic conditions, metal ions replace protons to form other species, such as hydroxometalcomplexes. These complexes are soluble in some cases $(\mathrm{Cd}, \mathrm{Ni}$, and $\mathrm{Zn})$, while those of 
$\mathrm{Cr}$ and $\mathrm{Fe}$ are insoluble. The solubility and bioavailability of heavy metals can be influenced by a small change in the $\mathrm{pH}$ level.

Temperature also plays an important role in the adsorption of heavy metals. It has two major effects on the adsorption process. Increasing the temperature will also, increase the rate of adsorbate diffusion across the external boundary layer and in the internal pores of the adsorbate particles, because liquid viscosity decreases as temperature increases. It also affects the equilibrium capacity of the adsorbate, depending on whether the process is exothermic or endothermic. Temperature changes affect the stability of the metal ion species initially placed in solution; stability of the microorganism-metal complex depends on the biosorption sites, microbial cell wall configuration, and ionization of chemical moieties on the cell wall. An increase in the sorption capacity of lead, from 0.596 to 0.728 $\mathrm{mg} / \mathrm{g}$, was obtained when the temperature was raised from 25 to $40^{\circ}$ (Arjoon et al., 2013).

Heavy metal toxicity affects microbial population size, diversity, and activity, as well as their genetic structure. It affects the morphology, metabolism, and growth of microorganisms by altering the nucleic acid structure, disrupting the cell membranes, causing functional disturbance, inhibiting enzyme activity and oxidative phosphorylation, and causing lipid peroxidation, osmotic balance alteration, and protein denaturation (Fashola et al., 2016).

At lower initial solute concentrations, the ration of the initial molecules of solute to the available surface area is low; subsequently, the sorption becomes independent of the initial concentration. However, at higher concentrations, the sites available for sorption become fewer compared with the molecules of solute present. Hence, the removal of solute is strongly dependent upon the initial solute concentration (Dhankharand Hooda, 2011). An increased metal uptake by increasing the initial metal ion concentration is a result of the increased driving force of the concentration gradient, rather than the increased initial metal ion concentration (Ghorbani et al., 2008). Several researches have also found similar results as this study (Soleimani et al., 2016).

The two most potent fungal isolates Alternaria alternata and Penicillium aurantiogriseum showing maximum tolerance up to $1000 \mathrm{ppm}$ of both cadmium and mercury metals are tested for potential microbes to remove these heavy metals from soil, sewage and industrial wastewater and the most efficient microbes for removal of heavy metals from liquid media are identified. Further studies to realize their potential for removal of heavy metals by these fungal strains that mixed with some agricultural wastes as biosorbent agents from industrial effluents are in progress.

\section{References}

Akhtar, N., Iqbal, M., Zafar, S.I. and Iqbal,J. (2008): Biosorption characteristics of unicellular green alga Chlorella sorokiniana immobilized in loofa sponge for removal of $\mathrm{Cr}(\mathrm{III})$. J. Environ. Sci.20:231-239.

Anahid, S., Yaghmaei, S. and Ghobadinejad, Z. Heavy metal tolerance of fungi. ScientiaIranica. 18(3):502-8.

Arjoon, A., Olaniran, A. andPillay, B. (2013): Co-contamination of water with chlorinated hydrocarbons and heavymetals: Challenges and current bioremediation strategies. Int. J. Environ. Sci. Technol.10, 395-412.

Ayangbenro,S.A. and Babalola, O. O. (2017): A New Strategy for Heavy Metal Polluted Environments: A Review of Microbial Biosorbents Int. J. Environ. 
Res. PublicHealth 2017, 14, 94; doi: 10.3390/ijerph14010094.

www.mdpi.com/journal/ijerph

Barnett H.L. and Hunter B.B. 1999. Illustrated genera of imperfect fungi. Fourth edition. Prentice Hall Inc.

Brar,S.K., Verma, M., Surampalli, R., Misra, K., Tyagi, R., Meunier, N. and Blais, J. (2006): Bioremediation of hazardous wastes-A review. Pract. Period. Hazard. Toxic Radioact. Waste Manag.10, 59-72.

Chang, J.S., Law, R. and Chang, C.C. (1997):"Biosorption of lead, copper and cadmium bybiomass of Pseudomonas aeruginosa PU 21," Water Research 31, 1651-1658.

Chojnacka,K. (2010): Biosorption and bioaccumulation-the prospects for practical applications. Environ. International. 36(3):299-307.

Congrrvarm, S., Dhanarani, S., Park, J. Dexillin, M. and Thanaraiselvi, K. (2007): Biosorption of chromium and nickel by heavy metal resistant fungal and bacterial isolates. J. Hazard.Mater.146:270-277.

Costa, A.D., Carlos, A. and Pereira, F. (2001): "Bioaccumulation of copper, zinc, cadmium and lead by Bacillus sp., Bacillus cereus, Bacillus sphaericus and Bacillus subtilis," Brazil.J.Microbiol.32, 1-5.

Dhankhar R. and Hooda A. (2011): Fungal biosorption-an alternative to meet the challenges of heavy metal pollution in aqueous solutions. Environ. Technol. 32(5):467-91.

Domsch K. H., Gams W. and Anderson T.H., 1980. Compendium of soil fungi. London, England: Academic Press.

Ezzouhri, L., Ruiz, E., Castro, E., Moya, M., Espínola, F., Cherrat, L., Er-Raioui, H., Lairini, K. (2010): Mechanisms of lead uptake by fungal biomass isolated from heavy metals habitats. Afinidad. 2010;
67(545).

Fashola, M., Ngole-Jeme, V. and Babalola, O. (2016): Heavy metal pollution from gold mines: Environmental effects and bacterial strategies for resistance. Int. J. Environ. Res. Public Health, 13, 1047.

Filipović-Kovačević Ž, Sipos L and Briški F. (2000): Biosorption of chromium, copper, nickel and zinc ions onto fungal pellets of Aspergillus niger 405 from aqueous solutions. Food Technol. and Biotechnol. 38(3):211-6.

Friberg, L., Elinder, C. G.andKjellstrom, T. (1992): Environmental Health Criteria 134: Cadmium. World Health Organization, Geneva, Switzerland.

Fu,F.and Wang,Q. (2011): Removal of heavy metal ions from Wastewaters: a review. J.Enviro.Manag., 92 (3), 407-418.

Gadd,G.M. (2000). Bioremedial potential of microbial mechanisms of metal mobilization and immobilization. Curr. Opin. Biotechnol.11, 271-279.

Ghorbani F, Younesi H, Ghasempouri SM, Zinatizadeh AA, Amini M, (2008): Daneshi A. Application of response surface methodology for optimization of cadmium biosorption in an aqueous solution by Saccharomyces cerevisiae. Chem. Engin. J. 145(2):267-75.

Ghoslan, H.A., Sabry, S.A. and Amer, R.A. (1999): "Bioaccumulation of nickel, cobalt and cadmium by free and immobilized cells of Pseudomonassp," Fresenius Environmental Bulletin 8, 428-435.

Han, R., Zhang, J., Zou, W., Shi, J. and Liu, H. (2005): Equilibrium biosorption isolation for lead ion on Chaff. J. Hazanl. Mater. B125: 266-271.

Hashim, M.A., Mukhopadhyay, S., Sahu, J.N. and Sengupta, B. (2011): Remediation technologies for heavy metal contaminated groundwater. J. Enviro. Manag., 92(10):2355-88.

Ho.T.H, Li, W.T., Sun, Y.M. and Chang,F.L. 
(2006): The effect of environmental factors on the adsorption of heavy metals from water by Aspergillus terreus (in Chinese). J.Nat. Kaolistung Univ. Appl.Sci. 35:335-346.

Huang,C. and Huang.C.P. (1996): Application of Aspergillus oryzae and Rhizopusoryzae for $\mathrm{Cu}$ (II) removal. Water Res.30.1985-1990.

Huang, C.P., Westman, D., Huang, C. and Morehart,A.L. (1988): The removal of cadmium (II) from dilute aqueous solutions by fungal biosorpent. Water Sci.Technol. 20:369-376.

Iqbal, M. and Edyvean, R.G. J. (2004): Biosorption of lead, copper and zincions on loofa sponge immobilized biomass of Phanerochaete chrysosporium. Minerals Engineering 17 (2), 217-223.

Kacprzak, M. and Malina, G. (2005):The tolerance and $\mathrm{Zn}^{2+}, \mathrm{Ba}^{2+}$ and $\mathrm{Fe}^{3+}$ accumulation by Trichodermaatro viride and Mortierella exigua isolated from contaminated soil. Canadian journal of soil science. 85(2):283-90.

Kapoor, A., Viraraghavan, T. and Roy Cullimore,D. (1999): Removal of heavy metals using the fungus Aspergillusniger. Bioresour. Technol.70:95-104.

Kefala, M.I.,Zouboulis, A.I. and Matis, K.A. (1999): Biosorption of cadmium ions by actinomycetesand separation by flotation. Environmental Pollution 104, 283-293.

Kumar,R., Singh,P.,Dhir,B.,Sharma,A.K. and Mehta,D. (2014): Potential of some fungal and bacterial species in bioremediation of heavy metals. J.Nuclear Physics, Material Sciences, Radiation and Application.1 (2): 213223.

Lesmana, Sisca O., Febriana, Novie, Soetaredjo, Felycia, Suarso, Jaka, Ismadji and Suryadi. (2009): Studies on potential applications of biomass for the separation of heavy metals from water and wastewater. Biochem.Engin. J.44 (1), 19-41.

Lin,C.C.and Lin, H.L. (2005): Remediation of soil contaminated with the heavy metal (Cd2+). J. Hazard. Mater.122, 7-15.

Malik,A. (2004):"Metal bioremediation through growing cells," Environ. Intern. J. 30, 261-278.

Mani,D.and

Kumar,C. (2014):Biotechnological advances in bioremediation of heavymetals contaminated ecosystems: An overview with special reference tophytoremediation. Int. J. Environ. Sci. Technol. 11, 843-872.

Mehdipour, S., Vatanpour, V. and Kariminia, H.-R (2015): Influence of ion interaction on lead removal by a polyamidenano filtration membrane. Desalination 362, 84-92.

Mukhopadhyay, S. and Maiti, S.K. (2010): Phytoremediation of metal mine waste. Appl. Ecol. Environ. Res.8, 207-222.

Namasivayam, C. and Kadirvelu, K. (1999): Uptake of mercury (II) from wastewater by activated carbon from an unwanted agricultural solid by-product: coirpith. Carbon 37 (1), 79-84.

Nilanjan Das, R. Vimala and P. Karthika, (2008): Biosorption of heavy metals An overview. Ind. J.Biotechnol.7, 159 169.

Ozdemir, G., Ceyhan, N., Ozturk, T., Akirmak, F. and Cosar, T. (2004): "Biosorption of chromium (VI), cadmium (II) and copper (II) by Panteo sp. TEM18," Journal of Chemical Engineering102, 249-253.

Pacheco, P.H., Gil, R.A., Cerutti, S.E., Smichowski, P. and Martinez, L.D. Biosorption: A new rise for elemental solid phase extraction methods. Talanta. 85(5):2290-300.

Pan, X., Wang, J. and Zhang, D. (2005): Biosorption of $\mathrm{Pb}(\mathrm{II})$ by 
Pleurotusostreatus immobilized in calcium alginate gel. Process Biochem. 40:2799-2803.

Pardo, R., Herguedas, M., Barrado, E. and Vega, M. (2003): "Biosorption of cadmium, copper,lead and zinc by inactive biomass of Pseudomonasputida," Analytical and BioanalyticalChemistry 376, 26-32.

Park,D., Yun,Y.-S. and Park, J.M. (2010): The past, present, and future trends of biosorption. Biotechnol. Bioprocess Eng. 15, 86-102.

Prigione, V., Zerlottin, M., Refosco, D., Tigini, V., Anastasi, A., Varese, G.C. (2009): Chromium removal from a real tanning effluent by autochthonous and allochthonous fungi. BioresourceTechnology.100 (11):27706.

Puranik, P.R. and Paknikar, K.M. (1999):"Biosorption of lead, cadmium and zinc by Citrobacterstrain MCM B181: characterization studies," Biotechnology Program 15, 228-37 (1999).

Rama Rao,V.S.K.V., Akhtar, N. and Maruthi, M.P. (1997):"Isolation of a cadmium tolerant Curvularia sp. for polluted effluent," Current Science 73, 453.

Rao, K.S., Mohapatra, M., Anand, S. and Venkateswarlu, P. (2010):Review on cadmium removal from aqueous solutions. International Journal of Engineering, Science andTechnology. 2 (7), 81-103.

Rasmussen, L.D., Sørensen, S.J., Turner, R.R. andBarkay, T. (2000): Application of a mer-lux biosensor for estimating bioavailable mercury in soil. Soil Biol. Biochem.32, 639-646.

Renge,V.C., Khedkar, S. V. and Pandey Shraddha, V. (2012): Removal of heavy metals from wastewater using low cost adsorbents: are view. Scientific Reviews and Chemical
Communications 2(4), 580-584.

Say, R., Denizli, A. and Arica,M.Y. (2001):"Biosorption of cadmium (II), lead (II) and copper (II)with the filamentous fungus Phanerochaete chrysosporium,"

BioresourceTechnology 76, 67-70.

Sharma, P.K., Balkwill,D.L; Frenkel, A. and Vairavamurthy,M.A. (2000): A new Klebsiellaplanticola strain (Cd-1) growsanaerobically at high cadmium concentrations and precipitates cadmium sulfide. Appl. Environ. Microbiol. 66, 3083-3087.

Słaba, M. and Długoński, J. (2011): Efficient $\mathrm{Zn}{ }^{2+}$ and $\mathrm{Pb}^{2+}$ uptake by filamentous fungus Paecilomycesmarquandii with engagement of metal hydrocarbonates precipitation. International Biodeterioration and Biodegradation. 65(7):954-60.

Solarsk, S., May, T., Roddick, F.A. and Lawrie, A.C. (2009): "Isolation and screening of natural organic matterdegrading fungi, Chemosphere 75, 751758.

Soleimani,N., Fazli,M., Ramazani,A. and Mehrasbi,M. (2016): Application of live, dead and dried biomass of Aspergillus versicolor for cadmium biotreatment. J.Hum, Environ, Health Promot. 1(2):87-98.

Srivastava, N.K. and Majumder, C.B. (2008): Novel biofiltration methods for the treatment of heavy metals from industrial wastewater. Journal of Hazardous Materials. 151(1):1-8.

Sun,Y., Horng, C.Y., Chang, F. Cheng,L. and Tian,W. (2010): Biosorption of lead, Mercury and Cadmium ions by Aspergillus terreus immobilized in a natural matrix. Polish J.Microbiol. 59(1): 37-44.

Tak, H.I., Ahmad, F. and Babalola, O.O. (2013): Advances in the application of plant growth promoting rhizobacteria in 
phytoremediation of heavy metals. In Reviews of Environmental Contamination and Toxicology; Springer: New York, NY, USA, pp. 3352.

Trujillio, E.M., Sprinti. M. and Zhuang, H. (1995): Immobilized biomass: a new class for heavy metal selective ion exchangers, pp.225-270. In: Sengupta, A.K. (Ed.). Ion exchange technology: advances in pollution control. Technomic Publishing Co., Pennsylvania.

Volesky B, (1986): Biosorbent materials, Biotechnol Bio EngSymp, 16, 121-126.

Volesky, B. and Holan, Z. R. (1995): Biosorption of heavy metals. Biotechnology Progress 11 (3), 235250.

Wang J, and Chen C. (2009): Biosorbents for heavy metals removal and their future. Biotechnology advances. 27(2):195226.

Watanabe, M., Kawahara, K., Sasaki, K. and
Noparatnaraporn, N. (2003): "Biosorption of cadmium ions using a photosynthetic bacterium, Rhodobacter sphaeroides $\mathrm{S}$ and a marine photosynthetic bacterium, Rhodovulum sp. and their biosorption kinetics," Journal of Bioscience and Bioengineering 95, 374-378.

Yan.G. and Viraraghavan, T. (2003): Heavy metal removal from aqueous solution by fungus Mucor rouxii. Water.Res.37:4486-4496.

Yang, T., Chen, M.-L. And Wang, J.-H. (2015): Genetic and chemical modification of cells for selective separation and analysis of heavy metals of biological or environmental significance. TrAC Trends Anal. Chem., 66, 90-102.

Zhou, J.L. (1999): Zn biosorption by Rhizopus arrhizus and other fungi. Applied Microbiology and Biotechnology.51 (5):686-93.

\section{How to cite this article:}

Bahobil, A., R.A. Bayoumi, H.M. Atta and El-Sehrawey, M.M. 2017. Fungal Biosorption for Cadmium and Mercury Heavy Metal Ions Isolated from Some Polluted Localities in KSA. Int.J.Curr.Microbiol.App.Sci. 6(6): 2138-2154. doi: https://doi.org/10.20546/ijcmas.2017.606.253 